\title{
Institutional Arrangement for Food Price Stabilization and Market Distribution System: Study of Chili Commodity in Banyuwangi Regency
}

\author{
Adhitya Wardhono, Yulia Indrawati ${ }^{*}$, Ciplis Gema Qori'ah, M. Abd. Nasir \\ Faculty of Economics and Busines - Univeristy of Jember
}

\begin{abstract}
The fluctuating development of chili prices implies that the maintained supply of chili is very important to maintaining the stability of food prices. The value chain integration of the chili commodity from upstream to downstream supported by the availability of adequate infrastructure and institutions is the main prerequisite in increasing the productivity of chili commodities. The purpose of this study is (1) to give a description of the chili commodity marketing chain in Banyuwangi Regency; (2) analyze the determinants of structure, conduct, and performance of the chili commodity market in Banyuwangi Regency. The analytical method used consists of the Autoregressive Integrative Moving Average (ARIMA) and Structure Conduct Performance (SCP) models. The results of the study show that price determination was based on market mechanisms and collective agreements for farmers who partner with collectors and food processing industries. However, the lack of price and knowledge information in market analysis and projections of price movements and the absence of special institutions that deal with chili governance and limited use of technology have led to the emergence of asymmetrical information from chili businesses and the growth of new players in the trade system that dominates the chili trade. The chili market structure tends to oligopsony, which has the power to influence market prices and is concentrated, causing little competition between chili traders in Banyuwangi Regency.
\end{abstract}

\section{INTRODUCTION}

Chili (Capsicum annuum L) is one of the main food commodities in Indonesia which has a high economic value in meeting domestic and export needs. The need for chili for big cities with a population of one million or more is around 800,000 tons / year or 66,000 tons / month. In certain seasons such as religious holidays, chili needs usually increase by about $10-20 \%$ of normal needs. While the level of national chili productivity over the past five years has been around 6 tons / ha, so to meet the monthly needs of urban communities a chili harvest area of around 11,000 ha / month is needed. On the other hand, the need for chilli for export reached 536.38 tons in 2015 and Indonesia's fresh chili imports in 2015 only amounted to 42.56 tons [1]

The availability of chili supply in meeting domestic needs becomes very important especially in mitigating the volatility of chili prices. The price of red chili in the domestic market in July 2017 experienced a slight decrease of $8.66 \%$ compared to June 2017 [2]. However. when compared to July 2016, the price of red chili experienced a significant decrease of $16.12 \%$. For cayenne pepper, the price also slightly decreased by $7.16 \%$ compared to June 2017 , and when compared to July 2016, the price of cayenne pepper increased by $10.89 \%$ [3]. National chili prices have not been stable for one year. This condition is shown by the coefficient of diversity (KK) monthly prices for July 2016 to July 2017 are high, amounting to $28.32 \%$ for red chillies and $45.03 \%$ for cayenne peppers. Price disparity between regions in July 2017 is quite high with the monthly KK among regions for red chili reaching $38.90 \%$ and cayenne pepper reaching $32.07 \%$ [4] .

Banyuwangi Regency is one of the largest chili production centers in East Java Province which has 3,760 ha of chili harvest area in 2017 with 11,818 tons of red chili and 19,859 tons of cayenne [5]. As one of the largest chili production centers in East Java, the Banyuwangi Regency Government focuses on the chili plant center program at the national level. This was proven by the establishment of a chili crop development program in 16 districts as centers of chili plants. Nine large chili development centers are Srono, Cluring, Gambiran, Singojuruh, Songgon, Siliragung, Genteng, Sempu, and Kalibaru, while the development of cayenne pepper is in eight districts including Wongsorejo, Purwoharjo and Cluring [5].

The development of chili production in Banyuwangi Regency in 2017 experienced a fluctuation in 2017, where the production of red chili tends to decrease the harvested area with an increased planting area, causing the amount of production to also decrease. This is due to the decreasing chilli selling price so that many farmers delay planting and chili harvest [6]. While other factors are climax anomalies that are difficult to predict due to the dry season and declining purchasing power while supplies are abundant. The chili planting period on dry land or tegal is the beginning of the dry season, which is April-June and on the former paddy fields, namely the end of the rainy season in August-September .

Corresponding author: yulia.feb@unej.ac.id 
The decrease in chili productivity was caused by several factors, namely unfavorable seasons, inefficiency of production factors, deteriorating land conditions due to excessive chemical substances and various types of red chili varieties that were less adaptive to the conditions of farming areas. Likewise, with the production of cayenne which declined at the end of 2017, compared to August which was able to produce 7,918 tons with a harvest area of 1,101 ha and a planting area of 34 ha [8].

The fluctuating chili price development has implications that maintaining the supply of chili becomes very important in maintaining food price stability. Integration of chili commodity value chains from upstream to downstream supported by the availability of adequate infrastructure and institutions is a major prerequisite in increasing the productivity of chili commodities. This is because a decrease in productivity drives up prices with increasing demand, while excess supply also causes prices to plummet, especially at the farm level. Besides being caused by climate anomalies, distribution or marketing chains also determine the volatility of chili prices. The price of ordinary chili reaches Rp. 24,000/ kg and small chili reaches Rp. 12,200/ kg is still lower than East Java Province where for regular chili is Rp. $24,147 / \mathrm{kg}$ and small chili is Rp. $16,460 / \mathrm{kg}$ [9].

The cause of the phenomenon of a surge in chili prices in the period of two months in 2017 is not only focused on the stock of chili, because the average supply of chili is sufficient, but prices have fluctuated. This is due to disruptions in the supply chain, therefore since November 2017 the Ministry of Agriculture has cooperated with the Ministry of Trade, the Ministry of SOEs, the Provincial Government, the Regency Government, PT Indonesian Trading Company (PPI), and farmer groups in the special region [10]. The effectiveness of the marketing chain of horticultural commodities such as chili is largely determined by the structure and efficiency of the marketing chain to the final consumer at a price level [11]. Structure, conduct and performance (SCP) analysis is one method to see the structure and behavior of market participants in chili commodities. This study is to analyze the structure, conduct, and performance (SCP) of the chili commodity market in Banyuwangi as the largest chili-producing center in East Java Province.

\section{LITERATURE REVIEW}

Inflation is a tendency to increase in general prices continuously. An increase in the price of one or two items alone cannot be called inflation, unless the increase extends to (resulting in an increase) a large part of the price of other goods. The increase in prices caused by seasonal factors (for example ahead of the holidays), or which occur only once (and have no further effect) is not called inflation [12].
Inflation can be classified as follows:

1. Low inflation $(<10 \%$ a year), characterized by slow increases in price with a small percentage.

2. Moderate inflation ( $10 \%-30 \%$ a year), characterized by relatively rapid price increases or needs to be watched out for their impact on the economy.

3. Severe inflation $(30 \%-100 \%$ a year $)$, marked by a significant increase in prices and sometimes runs in a relatively short time and has the nature of acceleration, which means the prices of this week or month are higher than the previous week or month .

4. Hyperinflation ( $>100 \%$ a year), where inflation is the most severe result. People no longer want to save money, the value of money has fallen sharply, so it is exchanged for goods. Prices have risen five to six times.

Rational expectation (RE) is defined identical to the best guess of future or optimal predictions using all information. RE assumes that the predicted outcomes do not differ systematically from the market equilibrium results [13]. As a result, RE does not differ systematically from equilibrium results. That is, RE assumes that people do not make systematic errors when predicting the future, and the deviation from perfect foresight is only random.

For example, if $\mathrm{P}$ is the equilibrium price determined by the interaction of demand and supply. So the RE theory states that actual prices will only deviate from expectations if there is an information shock caused by unexpected information when expectations are formed. In other words ex ante, the actual price is the same as rational expectations:

$$
\begin{aligned}
& P=P *+\epsilon \\
& E[P]=P *
\end{aligned}
$$

Where $\mathrm{P} *$ is the rational expectation and $\varepsilon$ is the random error term which has zero and independent mean.

The RE theory was developed in response to the weaknesses of the adaptive expectation theory which bases future expectations based on past values. The RE hypothesis supports radical conclusions in economic decision making such as ineffective policy propositions developed by Thomas Sargent and Neil Wallace. It was stated that if the central bank (in this case the Federal Reserve) reduces unemployment through expansive monetary policy, then economic actors will anticipate the effects of policy changes and increase inflation expectations, so this will cause an increase in money supply. RE theory was also adopted in the assumption of a modern New Keynesian macroeconomic model such as that developed by Stanley Fischer [14].

\section{RESEARCH METHODOLOGY}

This research uses primary data and secondary data. Primary data was collected using two types of structured questionnaires, for farmers and traders. The sampling technique is stratified random sampling involving three groups of producers or farmers both lar 
ge chili and cayenne pepper or small chili, large or wholesale traders and homogeneous retail traders.

The analytical method used consists of the Autoregressive Integrative Moving Average (ARIMA) model to predict chili price movements in Banyuwangi Regency, Structural Conduct Performance (SCP) to see the structure, behavior and performance, Stochastic Frontier Efficiency is used to analyze efficiency.

\section{RESULTS AND ANALYSIS}
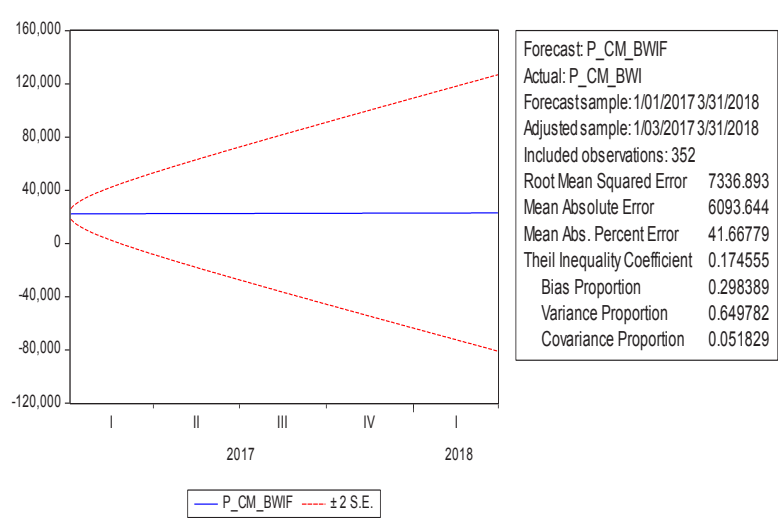

\subsection{Projections for Chili Prices in Banyuwangi Regency}

Forecasting the price movement of red chili and cayenne using Autoregressive Integrated Moving Average (ARIMA) for out-of-sample shows the value of Theil Inequality Coefficient is less than 0.2 , which shows good forecasting with ARIMA $(1,1,1)$ for red chili and ARIMA $(6,1,6)$ for cayenne pepper.

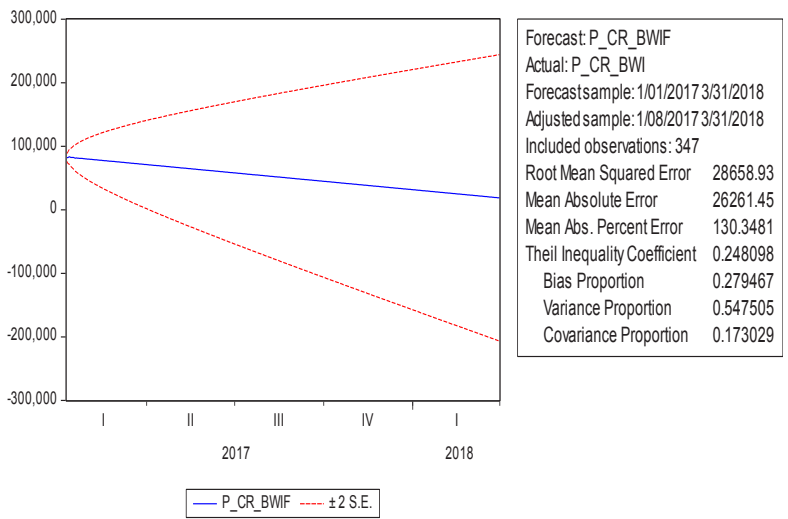

Fig 1. Autoregressive Integrative Moving Average (ARIMA) Projection of Red Chili and Cayenne Pepper Prices in Banyuwangi Regency

The projected development of red chili prices tends to be stable, while the price of cayenne peppers until March 2018 is predicted to show a declining trend. Fluctuations in the price of cayenne peppers were quite high due to the demand for cayenne peppers which tended to be higher for public consumption in Indonesia compared to large red chilies which were generally used for the food processing industry. Stabilization of chili prices, especially cayenne pepper, is very important, this is indicated by the government's efforts in suppressing prices in the past year through maintaining the supply chain of chili commodities and increasing chili productivity [15].

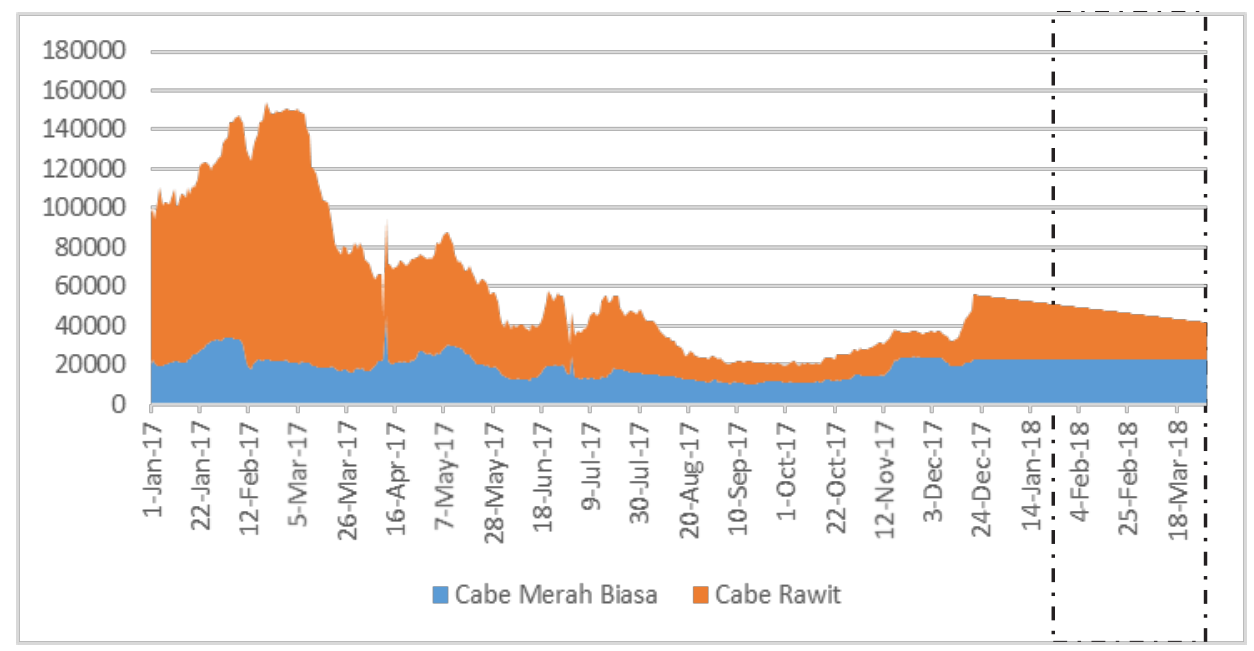

Fig 2. Projected Price Trends for Big Red Chili and Cayenne Pepper in Banyuwangi Regency

The price range of chili at the farmer level with retail has a quite large difference due to the length of the distribution chain that must go through large traders or wholesalers. This is very apparent in 2017 where at the farm level the price per $\mathrm{kg}$ reaches IDR 5,000 per $\mathrm{kg}$, but at the retail level the price level is quite high up to IDR 110,000 per $\mathrm{kg}$. The average Break Even Point (BEP) for cayenne farmers is Rp. $12,000 / \mathrm{kg}$ and when high rainfall reaches Rp. 15,000 / kg, while if there is a risk of damage, the BEP is in the range of Rp. 25,000 to Rp. $30,000 / \mathrm{kg}$ meaning that there is a big difference in price with a BEP value of Rp. 7,000 / kg, so that many farmers lose money. Meanwhile, when viewed from the price at the level of large traders, it is large enough to 
reach a difference of $\mathrm{Rp} .80,000$ per $\mathrm{kg}$ and at the retail level at Rp. 60,000 per kg. Supply chain management and chili marketing are very important in controlling prices and farmers also do not experience losses due to falling selling prices. This implies, the motivation of farmers to grow chili is decreasing in line with the decline in selling prices below the BEP.

\subsection{Institutional Patterns of Chili Business in Banyuwangi Regency}

The success of the management of chili cultivation is not only determined by good cultivation techniques in an effort to increase production productivity, but also needs to be supported by a good institutional pattern that is present among businesses and also policy makers in this case the government. Institutional strengthening in chili cultivation must be carried out integrally from upstream to downstream, from on-farm to off-farm which involves each component in the interaction space of each production chain to marketing. Important agents that play a role in the chili commodity are the government, farmers with farmer groups or farmer associations, collectors, retailers and end consumers. In each business chain, each business actor has a role with diverse background of knowledge and understanding and policies or in other words there is a possibility of asymmetric information that is present in the space of interaction between business actors. This has implications for the occurrence of chili price volatility.

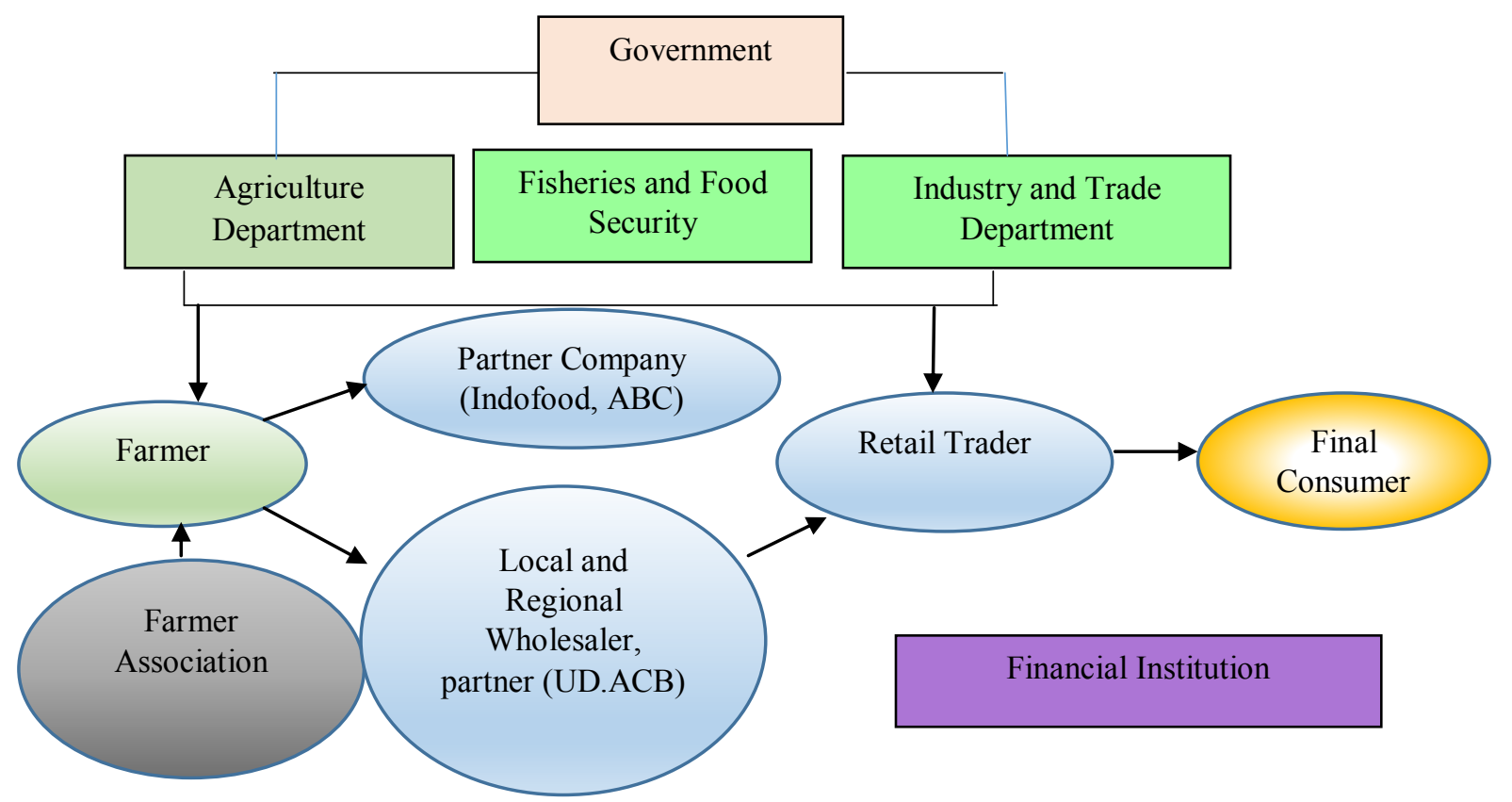

Fig 3. Pattern of Interaction of Business Actors in Chili Cultivation in Banyuwangi Regency

Broadly speaking, the pattern of interaction between all actors in the cultivation business of chili both large chili and cayenne pepper is not much different, namely having an integrated relationship with one another in an institutional management from upstream to downstream. 1). In terms of cultivation techniques, farmers generally have expertise based on experience that has gone down and down and prioritizes intuition and speculation. The chili planting season is the beginning of the dry season, which is April-June for dry land or tegal, and the end of the rainy season, namely August to September. For large red chili farmers generally start the planting season in August to September, while in April, May, June and July the planting season in the Jember Regency. This is based on considerations other than seasonal factors, to avoid oversupply which causes low prices, because the growing season in other regions such as Jember Regency. 2). The existence of farmers 'groups or chili farmers' associations is less desirable in some farmers this is due to the association of farmers or farmer groups considered ineffective or does not provide meaningful feedback for farmers. 3). The partnership pattern established between farmers and partner companies of several farmers is as a merchant trader. The partner companies in Banyuwangi Regency are UD. Alam Cabe Banyuwangi in Genteng District. The partnership pattern is based on the principle of mutual benefit and trust. In this case farmers act as collectors who sell their products to partners in accordance with the agreement with the unit amount as in the cooperation contract with a fixed price in accordance with the agreement value, even though the market price is fluctuating. The partnership pattern is considered by farmers to provide more price certainty, even though when the price in the market is higher than the partner and the farmer experiences a decrease in profit or even loses, the loss can be covered for the next production period with a relatively stable price from the partner. Apart from being a supplier of chili to partners, farmers also sell part of their production directly to the wholesale market, if the supply for partners has been fulfilled. While other partner companies are industrial companies such as Indofood, 
$\mathrm{ABC}$ for processed food products. Not all farmers can partner because there are technical requirements that must be followed. 4). The pattern of relations between farmers and the government, especially in the provision of seeds to technical assistance related to the cultivation of chili through counseling and other technical guidance. But what is still an obstacle in the pattern of this relationship is farmers' trust in the government is still low. While in terms of financing, farmers generally use their own capital, or group loans and some others still use banking services. 5). Until now, financial institutions at the farmer level are still carried out individually, and some others use their own business capital. Insurance for horticultural crops is still not utilized by farmers or traders, which is very important in helping to risk the risk of crop failure due to climate anomalies and other non-technical factors. Farmers and traders prefer to use private capital for business and if there are losses due to climate anomalies and prices, are considered business risks and speculate on subsequent production or from other businesses or switch to the planting patterns of other commodities such as rice and other horticultural crops. 6). In terms of prices, all farmers do not know information about prices, only based on speculation and previous price information. Meanwhile, if the partners are considered to provide more certainty in prices, most farmers are more interested.

\subsection{Analysis of the Structure, Behavior and Performance of the Chili Market}

Market structure refers to the characteristics of market organizations that tend to influence the behavior and performance of companies such as the number of sellers, the level of freedom of entry and exit and product differentiation. The main elements in the market structure consist of market share, market concentration and barriers to entry.

Market concentration is measured using the Gini coefficient and the Lorenz curve [16]. The proportion of sellers is divided into 7 frequency classes from the smallest to the largest quantity. The Gini coefficient is in the range of values between 0 and 1 where values close to 0 indicate perfect similarity of market participants and those close to 1 indicate inequality or inequality between market participants. While the Lorenz curve shows an even distribution among market participants when approaching the similarity line and if away from it shows an imbalance.

The average number of chilies sold by big traders is 48 tons per person per planting season with an average selling price of Rp. 18,000/ $\mathrm{kg}$ from the total of all respondents, so the average sales result is $\mathrm{Rp}$. $833,904,762$ per planting season. The Gini coefficient shows a value of 0.86 which means that market participants in this case are large traders who have a high concentration with relatively little competition. The high difference in the number of chilies sold and the capital owned, causes variations among traders. Disparity in sales between traders gives an indication of the oligopsony market structure, that is, if there is only a single buyer or several buyers, then some of these buyers have oligopsony power. In this structure the buyer has the power to influence the price of the goods. With oligopsony power, buyers can buy goods below market prices when compared to prices prevailing in competitive markets.

Table 1. Gini Coefficients for Wholesalers in Banyuwangi Regency

\begin{tabular}{|c|c|c|c|c|c|c|}
\hline Sales Amount (Kg) & Saler & $\begin{array}{c}\text { Saler } \\
\text { propotion }\end{array}$ & $\begin{array}{c}\text { Saler } \\
\text { Cummulative (\%) }\end{array}$ & Omzet (Rp.) & $\begin{array}{c}\text { Sales } \\
\text { Proportion }\end{array}$ & $\begin{array}{c}\text { Sales Cummulative } \\
(\%)\end{array}$ \\
\hline $1.000-26.500$ & 5 & 0.238 & 0.238 & $580,000,000$ & 0.033 & 0.033 \\
\hline $26.501-43.001$ & 7 & 0.333 & 0.571 & $2,782,000,000$ & 0.159 & 0.192 \\
\hline $43.002-59.502$ & 1 & 0.048 & 0.619 & $2,520,000,000$ & 0.144 & 0.336 \\
\hline $59.503-76.003$ & 1 & 0.048 & 0.667 & $6,850,000,000$ & 0.391 & 0.727 \\
\hline $76.004-92.504$ & 5 & 0.238 & 0.905 & $2,800,000,000$ & 0.160 & 0.887 \\
\hline $92.505-100.000$ & 2 & 0.095 & 1 & $1,980,000,000$ & 0.113 & 1 \\
\hline Gini Coefficient: 0,86 & \multicolumn{7}{l}{} \\
\hline
\end{tabular}

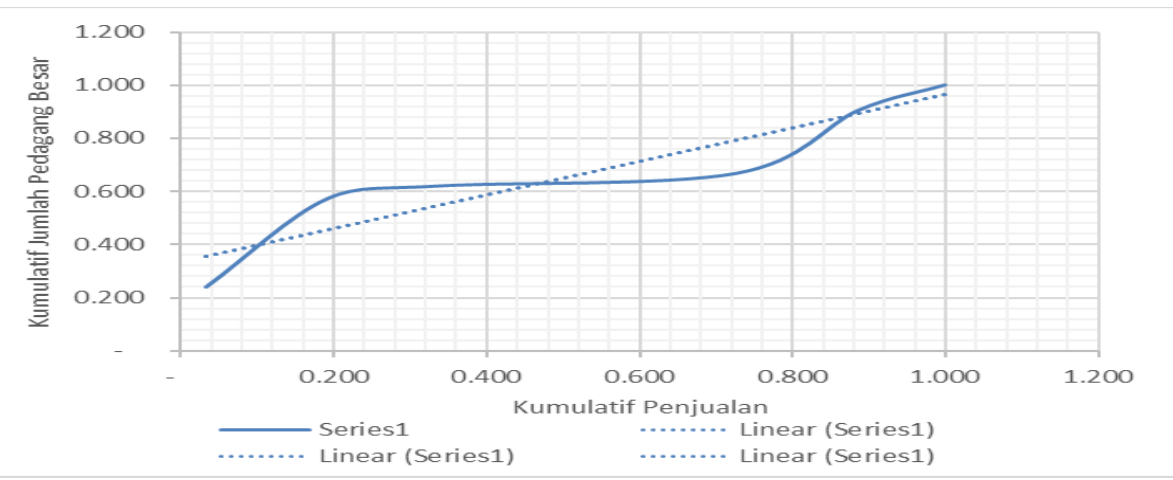

Fig 4. Relationship between the Amount of Traders and Sales of Chili in Banyuwangi Regency 
The average number of chilies sold by small traders or retailers is $16 \mathrm{~kg}$ per trader per planting season with an average selling price of Rp. $24,000 / \mathrm{kg}$ of the total respondents, so that the average sales result is $\mathrm{Rp}$. 375,714 per planting season. Table 1 shows the Gini coefficient with a value of 0.72 which means that market participants in this case are retail traders having a high concentration with relatively little competition. The high difference in the number of chilies sold and the capital owned, causes variations among traders. Disparity in sales between traders gives an indication of the oligopsony market structure, that is, if there are several buyers, then some of these buyers have oligopsony power. In this structure the buyer has the power to influence the price of the goods. With oligopsony power, buyers can buy goods below market prices when compared to prices prevailing in competitive markets.

Table 2. Gini Coefficients for Retail Traders in Banyuwangi Regency

\begin{tabular}{|l|l|l|l|l|l|l|}
\hline $\begin{array}{l}\text { Sales Amount } \\
(\mathrm{Kg})\end{array}$ & Saler & $\begin{array}{l}\text { Saler } \\
\text { propotion }\end{array}$ & $\begin{array}{l}\text { Saler } \\
\text { Cummulative (\%) }\end{array}$ & Omzet (Rp.) & $\begin{array}{l}\text { Sales } \\
\text { Proportion }\end{array}$ & $\begin{array}{l}\text { Sales } \\
\text { Cummulative (\%) }\end{array}$ \\
\hline $2-10$ & 1 & 0.143 & 0.143 & 830,000 & 0.316 & 0.316 \\
\hline $11-16$ & 4 & 0.571 & 0.714 & 360,000 & 0.137 & 0.452 \\
\hline $17-23$ & 0 & - & 0.714 & 0 & - & 0.452 \\
\hline $24-30$ & 2 & 0.286 & 1 & $1,440,000$ & 0.548 & 1 \\
\hline \multicolumn{7}{|l|}{ Koefisien Gini: 0,72} \\
\hline
\end{tabular}

Meanwhile, to calculate market concentration using Concentration ratio analysis. The results showed that the average ratio of the four largest companies (CR4) in the chili traders market was 0.381659 . This indicates that the market concentration of $38 \%$ is controlled by the four largest traders in the market.

While the analysis of the concentration of chili production is shown by the ratio of CR4 values calculated by looking at the four highest values in the total production of the largest companies against the total value of the total production of farmers. The CR4 value indicates the number 0.6488 which means that $64.88 \%$ of the chili farmers' production share is controlled by several large farmers. This shows that chili production in Banyuwangi is almost uncompetitive and there is a high imbalance between other farmers. By using 42 samples, $64.88 \%$ of production concentration was dominated by 4 large farmers while the remaining $35.12 \%$ was contributed by 38 small and medium farmers.

The average chili seller in Banyuwangi Regency does not have a business license. Only a few have business licenses, especially those with large business capital. Minimum Efficiency of Scale (MES) is a measurement for barriers to entry in the market. The MES value is obtained from the largest chili trader output percentage of the total chili trader output in an industrial area. The high MES will be a barrier for new traders to enter the market. MES values greater than 10 percent represent high entry barriers in a market. Based on the results of the MES analysis shows that in Banyuwangi Regency has a fairly high entry barrier with an MES value of 0.1048 or around 10.48 percent. This is due to being a chili trader who has sufficient capital in maintaining business continuity. Judging from the market structure that tends to be oligopsony with the dominance of certain traders having large capital, in addition to capital, new players in the chili trade business also have sufficient knowledge in analyzing market price volatility.

Analysis of the conduct or behavior of chili traders in this study includes pricing strategies, cooperation between economic actors, the use of information, and marketing functions.
The pricing strategy is based on standard operating procedures that have been determined based on recommendations from farmers and additional production costs. However, the price determination is not always agreed upon by the traders, so there is still a negotiation process between farmers and traders or collectors until an agreement on price is reached. Whereas traders distributing to end consumers have set prices in accordance with market prices and end consumers do not have the bargaining power of prices. The use of information in the form of information on transactions between farmers and wholesalers, wholesalers and retailers, retailers and consumers.

Various actions were taken to achieve the level of production efficiency of chilli farmers in Banyuwangi Regency especially large farmers aiming to maintain their existence and protect themselves from price fluctuations in the market. On average, large farmers in Banyuwangi establish partnerships with large companies such as ABC, UD Alam Cabe and Indofood which have high market share. This partnership is carried out every planting season because the average large farmer is also a trader and trader. The form of profit from this partnership is realized in the form of a contract agreement which includes the related price fixation so that when prices in the market generally fall due to an imbalance between demand and supply of chili, the price of chili farmers who partner will remain within normal limits. However, when the chili market price increases, farmers will not get too high a profit because the price is in the normal limit between production costs and production output. So that farmers are less likely to experience losses if related to price flutquations. Another obstacle that cannot be anticipated related to prices is unfavorable weather so that this condition can result in a decrease in supply due to a decrease in chili production. In addition, to maintain the existence and production results, especially for small farmers, they also take actions such as network expansion through cooperation with large farmers. The role of large farmers here collects all the smallholder products which are then distributed directly to companies or to large markets such as Jakarta, Surabaya, Bali, Kediri and even the local 
market of Banyuwangi itself. This strategy will help small farmers to maintain their existence and help to improve their efficiency in terms of sales costs and so on [18].

\subsection{Performance of the Chili Market}

The chili trade system chain creates price differences that appear in each chain.
Price adjustments are made by market participants, namely collectors or large traders, with costs incurred and profits received by market participants in the distribution of chili to end consumers. Farmer's share shows the size of the price received by farmers against the price paid by end consumers.

Table 3. Marketing Margin and Farmer's Share on the Chili Marketing Channel in Banyuwangi Regency

\begin{tabular}{|l|l|l|}
\hline Marketing Distribution Type & Margin (Rp./kg) & Farmer's Share (\%) \\
\hline Farmer- Retail & 13.000 & 45,83 \\
\hline Farmer- Wholesaler & 11.000 & 50 \\
\hline
\end{tabular}

The value of marketing margin affects the value of the farmer's share and marketing efficiency. The lower the marketing margin, the higher the farmer share value and the smaller the efficiency value. The marketing margin composition occurred at the end of 2017, where the price of chili was stable compared to the beginning of 2017 to exceed the normal limit of chili prices or the price at the farm level is below the break-even point (BEP).

Farmer margins indicate the amount of profits obtained by farmers from the total income received by the total costs incurred at the time of production.

Table 4. Gross Margin of Chili Farmers in Banyuwangi Regency

\begin{tabular}{|ll|}
\hline \multicolumn{2}{l}{ Revenue } \\
Cost: & Rp. 126.376 .190$, \\
a. Bibit & Rp. $678.571,-$ \\
b. Fertilizer & Rp. $635.929,-$ \\
c. Pestiside & Rp. $1.132 .500,-$ \\
d. Land Preparation & Rp. $693.476,-$ \\
e. Weeding & Rp. 594.524,- \\
f. Fertilization & Rp. $352.500,-$ \\
g. Harvest & Rp. $11.412 .619,-$ \\
h. Irrigation & Rp.8.756.897,- \\
i. Others & Rp. $1.186 .607,-$ \\
Total Cost & Rp. $25.443 .682,-$ \\
Gross Margin & Rp.100.932.508,- \\
\hline
\end{tabular}

\subsection{Stochastic Frontier Efficiency (SFA)}

While Stochastic Frontier Efficiency is used to analyze efficiency as a performance proxy to test the SCP hypothesis through output and efficiency as endogenous variables. In the SFA analysis several variables are used, namely the cost of input, labor and output. The results of the inefficiency model analysis with cross section data involved 42 sample farmers in Banyuwangi Regency to predict the level of efficiency of the chili business in Banyuwangi Regency.

Output $=5.1672-0.0395$ input cost -0.1635 labor + 0.9771 capital.

The equation above shows that the input components consisting of labor and capital have a significance value of each with a probability value of 0.050 and 0,000 less than the value of error tolerance of $5 \%(0.05)$. While input costs do not show a significant effect on production output indicated by the probability value of the input cost of 0.722 greater than the value of error tolerance of $5 \%$. This condition indicates that the capital and labor variables have a significant influence on the output of chili production. While input costs do not have a significant effect on chili production output. If seen based on the coefficient and probability values in the above equation, it shows the result that labor has a significant negative effect on production output with a coefficient value of -0.164 while capital shows a significant positive effect with a coefficient of 0.977 . This means that when there is an increase in labor by 0164 there will be a decrease in production output by 0.164 , then when there is an increase in capital by 0.977 it will increase production output by 0.977 . An increase in high labor input will reduce the amount of production output due to the implementation of law diminishing return so that increasing the amount of labor at a point will actually reduce production output [19]. Therefore, increasing labor productivity becomes very important in increasing chili production in Banyuwangi Regency.

\section{Conclusion and Recommendation}

Some conclusions from the results of the study are: 1. The chili supply chain in Banyuwangi Regency consists of several marketing distribution channels from upstream to downstream with various behavior of market participants in each chain. In general, the distribution of chili marketing in Banyuwangi Regency is more dominated by marketing destinations in several big cities 
outside Banyuwangi Regency, especially in Java and Bali.

2. Pricing is based on market mechanisms and collective agreements for farmers in partnership with traders and food processing industry companies. However, the lack of price information and knowledge in market analysis and projected price movements and the absence of specific institutions that deal with chili governance and the limited use of technology have led to asymmetrical information from the chili business actors and the growth of new players in the trade system that dominate the chili trade.

3. The chili market structure tends to oligopsony which has the power to influence market prices and is concentrated causing the small competition between chili traders in Banyuwangi Regency.

4. The chili business performance in Banyuwangi tends to be less efficient, as indicated by a small market margin and large farmers share, causing smaller efficiency.

Then some recommendations from this research are:

1. Optimizing the role of Gapoktan and Association of farmers and traders, together with the government through related work units (Agriculture Office, Fisheries and Food Security Service and Industry Office) and Regional Inflation Control Team (TPID) coordinate intensively in providing intensive information and price knowledge for all chili business actors. This is to mitigate the asymmetry of price information and price speculation actions.

2. Compile a complete balance of chili import export trade between regions within the Banyuwangi Regency and between regions outside Banyuwangi Regency, to analyze in more depth the movement of chili commodity flows between regions in both fresh and processed forms.

3. Preparing supporting infrastructure through the use of information technology that records movements in real time from all chili trade transactions conducted by all business actors that are more innovative and userfriendly.

4. Uphold the law of enforcement against business actors or new players who act speculatively that can hamper the supply chain and the instability of chili prices. This in the medium to long term changes the market structure to become more competitive.

5. Optimizing mutually beneficial business partnerships strengthened by legal instruments and contract farming.

6 . Increase chili productivity through proper cultivation techniques against the risk of climax anomalies and provide knowledge and build mind-sets of farmers and traders in helping to maintain the supply of chili and price control.

7. Optimizing the role of financial institutions in business financing to maintain business sustainability. The role of insurance for chili cultivation is very important in mitigating the occurrence of business risks. 8. Optimizing the potential of regional resources both natural and human, in developing chili agro-industry based on local economic empowerment through investment so as to increase the added value of chili commodities.

9. The development of chili agro-industry in the medium to long term is very important by preparing a business and infrastructure feasibility analysis.

10. Because chili price stability in the chili commodity value chain is crucial, it is important to form a comprehensive and integrative market intelligence system or market information system from upstream to downstream in an effort to mitigate asymmetric information on chili price volatility.

\section{References}

[1] T.C. Bailey. Multivariate statistical analysis for geographers. Journal of Regional Science, 38 (4):682-686 (1998).

[2] A.N. Berger, T.H. Hannan. The price-concentration relationship in banking. Review of Economics \& Statistics, 71 (2): 291-299 (1989).

[3] D. Carias, R. J.Keenan. Forest Policy and Economics Transaction cost theory of the fi rm and community forestry enterprises. Forest Policy and Economics, 42, 1-7 (2014)

[4] C. Eaton, A.W Shepherd. Contract Farming: Partnerships for Growth. Fao Agricultural Services Bulletin. 145, 1-161 (2001).

[5] S. Edwards, A.J. Allen, S. Shaik. Market structure, conduct and performance (SCP) hypothesis revisited using stochastic frontier efficiency analysis. American Agricultural Economics Association Annual Meeting, Long Beach, California, July 23-26 (2006).

[6] FAO. Agro-industrial supply chain management: concepts and applications (2007).

[7] A. Feyissa.. Grain market and rural livelihoods: A case of structure, conduct and performance of grain market in Lume Woreda of Oromiya region. Unpublished M.S. thesis, Lund University, Sweden (2009).

[8] G.J. Gereffi, Humphrey. The Governance of Global Value Chains. Review of International Political Economy, 12(1): 78-104 (2005).

[9] Goldsmith, Arthur. 1985. "The Private Sector and Rural Development: Can Agribusiness Help The Small Farmer" dalam World Development. Vol.B.10. Great Britain.

[10] Goldsmith, Arthur. 1985. "The Private Sector and Rural Development: Can Agribusiness Help The Small Farmer" dalam World Development. Vol.B.10. Great Britain.

[11] Gujarati, D.N. (2004). Basic Econometrics (4 ${ }^{\text {th }}$ ed.). New York: McGraw-Hill Book Company.

[12] Han, S. (2004). A Systematic Assessment of The Empirical Support for Transaction Cost Economics, 58 (September 2001), 39-58.

[13] Kaplinsky, R. 2000. Globalisation and Unequalisation: What Can be Learned from Value Chain Analysis. Journal of Development Studies 73 (2):117-146. 
[14] Kristen, J dan Sartorius, K. 2002. Linking Agribusiness and Small-Scale farmers in Developing Countries: Is there a New Role for Contract Farming?. Working Paper. 2002-13.

[15] Lazzarini, S.G., Chaddad, F.R. \& Cook, M.L. 2001. Integrating supply chain and network analyses, the study of netchains, Journal on Chain and Network Science, 1, 7-22

[16] Maertens, M., \& Vande Velde, K. (2017). Contractfarming in Staple Food Chains: The Case of Rice in Benin. World Development, 95, 73-87. https://doi.org/10.1016/j.worlddev.2017.02.011

[17] Maertens, M., \& Vande Velde, K. (2017). Contractfarming in Staple Food Chains: The Case of Rice in Benin. World Development, 95, 73-87. https://doi.org/10.1016/j.worlddev.2017.02.011

[18] Margetts, S. (2006). Measures of Market Concentration. Available on-line at http://www.revisionguru.co.uk/index.htm Accessed 15 September, 2014.

[19] Molyneux, Phil and William Forbes. (1995). Market Structure and Performance in European Banking. Journal of Applied Economics, 27:155- 